\title{
Disrupting Equilibrium: Working for Equity and Social Justice in Education for English Learners
}

\author{
Rachel G. Salas \\ University of Nevada Reno \\ United States
}

ABSTRACT: Many states in the western United States have seen an increase in the immigrant population. One state, in particular, has seen its foreign-born population increase $64.7 \%$ from 2000 to 2013. This increase in cultural and linguistic diversity foregrounds the 2013 passage of a specific Senate bill that "enacts provisions providing English language learning for students" in this state. The Senate bill also calls for the creation of a council to make recommendations to the appropriate governing boards on how best to meet the instructional needs of English Learners (ELs) in the state. LeChatelier's principle of equilibrium and Bell's interest convergence are used to analyze the recommendations. In addition, I use autoethnography and Latino critical race theory to interrogate the complexity of my dual membership, as an EL and an academic, in a cultural, political, and educational context.

KEYWORDS: autoethnography, teacher education, English language learners, LatCrit, interest convergence

An Autoethnographic Lens as Method

At Equilibrium: Kindergarten as an EL

Disrupting Equilibrium Begins

Interest-Convergence as an Interpretive Lens

Conclusion

References

Author Contact

Le Chatelier's principle of equilibrium states that if a change or stress is imposed on a system at equilibrium, the position of the equilibrium will shift in a direction that tends to reduce that change depending on the stress applied to the system (Last \& Slade, 2007). In other words, a system will always attempt to stay at equilibrium or counteract the change. To remain in balance, a system will make minor shifts to adapt or integrate the change or stress applied to it in an effort to reduce the effect of the change. In this paper, I apply Le Chatelier's principle of equilibrium in a global sense to an educational environment (system) and translate it to mean that a change in the status quo of an organization causes an opposing reaction by the affected system to accept minimal change to maintain stasis or the status quo. Garza (2008) verifies this reaction to change: "Leading for social justice incites political unrest because hegemonic culture will resist change that provides equity to all members of society" ( $p$. 163). 
The "system" referred to in this paper is the educational system in a state located in the western United States. Furthermore, the educational system specifically focuses on the K-12 school system, its teachers, administrators, and other personnel. This system at equilibrium consisted of a growing $E L$ population who were being underserved in the state's school system and an inadequate pool of qualified ESL or bilingual teachers. A look at the current condition of English Learners (ELs) in this state's educational system reflects an increase of ELs in a public school system that is not meeting their academic or linguistic needs. Evidence of this failure is highlighted by the recent Office of Civil Rights (OCR) settlement agreement with one of the school districts within the state that had been cited for not providing services to ELs within their district and mandated by OCR to provide appropriate services and qualified teachers for ELs. The state is considered one of 15 states in the United States with the highest enrollment of ELs in K-12 public schools (Ruiz Soto, Hooker, \& Batalova, 2015). The rapid increase of ELs in the state's educational system created unsustainable pressure on the system. This rapid increase was the impetus for the Senate bill that would create the Council to make recommendations to the appropriate state-level governing boards on how best to meet the instructional needs of English Learners (ELs) in the state. I found myself placed on this Council. In the discussion that follows I use autoethnography to provide my perspective of my time on the Council.

The National Assessment of Educational Progress (NAEP) data for 2015 show that $67 \%$ of fourth grade and $70 \%$ of eighth grade students identified as ELs scored below basic in reading. Data for 2013, the year I began my service on the Council, show $70 \%$ of fourth grade and $79 \%$ of eighth grade EL students scoring below basic in reading (National Center for Education Statistics, 2015). The status quo, or equilibrium per Le Chatelier's principle, was maintained by not having enough qualified ESL teachers available in the state to teach the EL population. The state had unsuccessfully attempted to ameliorate this situation, not by mandating that all current teachers and teacher candidates earn an ESL endorsement, but by seeking to recruit and hire ESLendorsed teachers from other states to teach the EL population.

Through autoethnography, I examine my position of duality, first as a member of a marginalized cultural and linguistic group whose educational progress at the state and national levels is marked by minor gains and even larger deficits when compared to their White monolingual English-speaking peers (NAEP, 2015), and second as a member of the academy placed on a state level council that could potentially enact positive and transformative change to the system that has marginalized English Learners (ELs). To provide a view into this dual position, I use an autobiographical counterstorytelling format (Yosso, 2006) situated within Latino Critical Race (LatCrit) theory to document the perpetuation of the status quo within an educational system.

Counterstorytelling provides a vehicle for marginalized voices to detail their lived experiences of racism and opposition (Yosso, 2006). Using a LatCrit lens highlights how the status quo or low EL student academic achievement within the educational system is used to subordinate Latino and other linguistically diverse students. LatCrit theory counters the claims that the educational system is meritocratic, equitable, and unbiased. It refutes the endemic deficit models often used to explain Latino low academic 
achievement and failure (Solórzano \& Bernal, 2001). It legitimizes the use of objective knowledge to contest racial and linguistic oppression through storytelling, counterstorytelling and other personal narratives (Solorzano \& Yosso, 2000). I use counterstorytelling to argue that the status quo or ELs' low academic attainment remains at equilibrium because of the interest convergence principle (Bell, 1980). I position Raquel as the counterstoryteller and the lens through which interest convergence is examined and discussed.

The basic premise of the interest convergence principle posits that any change that would benefit people or communities of color will only occur if the change will be a benefit to Whites or the White community (Bell, 1980). I use interest convergence as an analytical tool to discuss the impact of the recommendations that were presented by the Council to the various state governing boards for their vote that led to either approval or denial of each recommendation. To tell this story, I write this paper in two voices. I will use my given name, "Raquel," to present my counterstory that reflects my experience, thoughts, opinions, and the research on EL students in U.S. schools and "Rachel," the unwelcomed translation made by my kindergarten teacher, to discuss the views and opinions of the academy and the interplay of interest convergence.

\section{An Autoethnographic Lens as Method}

As a work of autoethnography, I position myself as an English learner (Raquel) and an academician and the subject of this study (Rachel). Situating myself in this manner allows for an insider lens on the internal conflict that $\mathrm{I}$, and others who experience a sense of duality, constantly wrestle within the cultural context of the academy. Autoethnography is an appropriate method to critique both the educational arena and my personal views and perspectives of my position in the academy, the presumed power the academy has over me, and my positioning as an English learner inside and outside of the academy. Boylorn and Orbe (2014) state: "Autoethnography is a powerful method for working with topics of diversity and identity. Autoethnography is predicated on the ability to invite readers into the lived experience of a presumed 'Other' and to experience it viscerally" (p.15).

My intent is to provide the reader with my lived experience. Chang (2008) argues that autoethnography is not just a study of self but also a study of the intricacies of the self in collaboration with others situated in a dynamic cultural context. I am the main character of my study with the caveat that I understand many have contributed to the data I use to tell my story. I do not use just memory to tell my story but reams of documents from the Council and subcommittee meetings, interviews, discussions, emails and informal conversations. Because this research is a work of critical ethnography, I understand the ethical charge I have to expose issues of unfairness and injustice as they pertain to my lived experience and story (Madison, 2012). To tell my story, I use Latino Critical Race counterstorytelling. Counterstorytelling is a tenet of Critical Race Theory (CRT) and Latino Critical Race Theory or LatCrit (Delgado Bernal, 2002). LatCrit provides a conceptual framework from which to examine racialized and 
covert discriminatory practices embedded in discourse patterns of the dominant culture. Through LatCrit I create counterstories by using Raquel's voice as a method of analysis to critique and question the dominant perspective and discourse of those in power. Counterstories provide a legitimate and valued vehicle for marginalized groups to voice and author stories that recount their views and perspectives. I use my stories in the voice of Raquel to illuminate experiences and issues of social and racial injustice in the education of ELs and to counter or expand upon Rachel's academician recitation of the facts documented in minutes and public records. In addition, I use counterstorytelling as a method to confront majoritarian discourse patterns that provide a singular lens that perpetuates deficit images of EL populations (Yosso, 2006). A majoritarian perspective is privileged and often provides a skewed and stereotypical view of culturally and linguistically diverse communities. Finally, I use Le Chatelier's Principle (Last \& Slade, 2007) and the theory of interest convergence (Bell, 1980, 2004; Driver, 2011; Milner, 2008) to interpret the data and show how acceptance or denial of the recommendations was directly related to the interest and benefit of the dominant group's desire to maintain equilibrium.

\section{At Equilibrium: Kindergarten as an EL}

I am of Mexican descent born of parents who emigrated from different parts of Mexico. My father was seven years old when his family entered the United States fleeing the Mexican revolution. My father entered the U.S. school system and quickly learned English, becoming the family translator and negotiator, a position familiar to many young ELs today. It was not until after serving his country in the U.S. Armed Forces for four years, wounded twice in battle, that he was granted U.S. citizenship. My father met my mother on a trip back to Mexico. A few years after meeting and courting her, they married in Mexico and returned to live in the U.S. My sisters and I were born in Los Angeles, California, into a Spanish-speaking household. Spanish was our first language; it was the language of familial love and maternal discipline. It was a language we practiced not just at home but on our yearly pilgrimage back to my mother's hometown in Mexico to visit family. While I spoke Spanish to my mother, my two older sisters would come home from school speaking English, so I began to learn new words and rehearsed my English language skills with them.

By the time it was my turn to start kindergarten, I knew how to spell my name, Raquel, and had enough English language skills to feel confident. My favorite part of kindergarten was art. I still have a clear image of art time. Art time was held in a long narrow gated section outside of the classroom. Rows of easels with large sheets of paper and big jars of bright primary color paint lined the chain-linked fence. The teacher handed out large wooden brushes with thick dark bristles as we marched our little aproned bodies outside to paint. My 5-year-old hand would gleefully dip the large paintbrush into the bright yellow, orange, and green paint jars and splash a colorful masterpiece. Like any good artist, I would sign my artwork in large irregular letters, "Raquel." It was the signature, not the bright colors that drew my teacher's attention. 
"Now that you are in America," she said to me one day, "your name is Rachel." She quickly set upon teaching me how to spell my new name so all future artwork would be signed "Rachel." I went home that day and informed my parents that they had been calling me the wrong name and demanded to be called Rachel. Even though my parents had registered me as Raquel, the name on my birth certificate, my kindergarten teacher and the school changed all academic documentation from Raquel to Rachel without my parents' permission. In kindergarten I became Rachel, forsaking my baptismal name for a more pronounceable Americanized translation of me.

I tell this story not just to offer an isolated incident of what happened to me in my childhood but as a mirror into the daily lives of English learners (ELs) in U.S. schools today. EL students are not just stripped of their names but of their cultural and linguistic identity and often they are forbidden or strongly discouraged from speaking their home language in school; that too is a scholastic memory I have (Sumaryono \& Ortiz, 2004). Stripping ELs of their given names and linguistic identity stills occurs in schools across our country; this has become the status quo or the school context at equilibrium (Bulale, 2016). It is this state of equilibrium that I have raged against as an educator of students who are culturally and linguistically diverse. This is the system of equilibrium I encountered as I began teaching at a midsized university in the western United States. As mentioned earlier, the EL school-aged population was increasing rapidly in the state and their academic progress, as measured by state level assessments and NAEP $(2011,2013,2015)$, reflected a system that was not meeting their academic needs. To tell the story of how the state at equilibrium was leaving the EL student population behind and how the Council I served on was attempting to disrupt equilibrium by recommending transformative change to improve the educational outcomes of ELs, I present my story in two voices. Rachel, the academician, will recount the efforts of the Council to disrupt the status quo while the voice of Raquel, the EL student, provides a counterstory and critique.

\section{In the Academy}

Rachel

Raquel

I had accepted a new teaching position at a midsized university in the western United States. I had left a smaller college in the southern portion of the same state to be closer to my family. A week or two into the new semester I was asked by the administration to sit on a new state-level council that would make recommendations about the educa-tional outcomes of English learners in
It was difficult leaving the southern part of the state with its large population of English learners (ELs) to accept a position in the northern section (of the same state) that had a smaller, yet growing, EL population. In the southern portion of the state, I felt that I had a real purpose and mission. I also felt I was in my element, "con mi gente" (with my people) as an EL and part of the "Comunidad" (community) surrounded 
the state. The state's EL population was rapidly increasing with Hispanics making up $27.5 \%$ and Asians $7.7 \%$ (Pew Research Center, 2013). Recognizing this rapid increase, the state legislature passed a Senate bill to address the English language learning needs of the student population. The Council's recommendations would focus on Curriculum, Policy, and the state-level Teaching English as a Second Language (TESL) Endorsement for teachers.

While I recognized this as an excellent opportunity to make an impact in the educational opportunities for English Learners in the state, I was hesitant to accept the invitation, fearing the constraints on my time and knowing the research and publication expectation of me as a new faculty member. A few days later, before I had made a final decision, I received a formal letter placing me on the newly formed Council, an invitation I felt I could not decline. by like-minded colleagues and students.

At the new university, I was one of a very small number of faculty of color and still had to figure out how supportive this new community would be regarding educational initiatives for EL students. I saw the invitation to sit on the Council as a double-edged sword: I should do it to make sure that ELs in this state get the best educational opportunities possible; I should not accept the invitation so I could focus on research and writing and prepare myself for tenure and promotion. The college had no tenured Latino/a faculty at that time and few Latino/a faculty had been granted tenure at the university. I assumed I was selected because I was currently the only tenure-track Latina faculty member with a bilingual and an English as a second language (ESL) academic background. Through my research and outreach, I felt I could help the EL population in the state just as well as sitting on the council. Before I could make a final decision, the decision was made for me. How would it look for the only tenure-track Latina faculty member to decline such an invitation sent by the chancellor of the university? I was too frightened of the consequences to find out.

In kindergarten, neither my family nor I were consulted as to which name I would prefer to use; the decision was made for me by my teacher. It was in the interest of the school and the teacher to rename me Rachel: it sounded American to them, and it was easier to pronounce than Raquel. All school documents including reports cards bear the new name, Rachel. My new university in the northern part of the state felt that it was in their interest to place me on this Council; while I was asked, I had not agreed until I received a formal letter recognizing my appointment. In both instances mentioned above, interest convergence dictated the outcome and the system remained in equilibrium. 
Rachel

I began my time on the Council with a huge learning curve, trying to understand the intricacies of the state's current EL education policy, curriculum, and politics. The committee was made up of university faculty, school district ESL leaders, a member of an EL think tank, the State Superintendent, local EL parents, and other stakeholders. The council quickly created three subcommittees to focus on Curriculum, Policy, and the Teaching English as a Second Language (TESL) endorsement. Each subcommittee was charged to review what was currently in place and with the support of the state department of education, community members, and other stakeholders to make recommendations on how to improve each area to best support the educational opportunities of the EL K-12 student population in the state. I was elected to chair the TESL subcommittee, and I accepted the challenge.

This paper will focus primarily on my experience as the chair of the TESL subcommittee.
Raquel

It was exciting to know that I might be able to roll up my sleeves and get involved in actual change for the EL student population of the state. While I realized that the Council was mostly made up of nonminority members, I felt each person was selected because we championed a common cause.

When I was nominated to chair a subcommittee, I wanted to withdraw my name because I did not feel I had enough background knowledge about the state. I knew the research on ELs in education and felt confident I could bring that knowledge to the subcommittee, but lacking experience teaching in the state meant I had a big learning curve ahead. I also wondered if the subcommittee would be able to bring about substantive change. I wanted real change to happen. Yes, I was idealistic, and I wanted to see real reform that could lead to exceptional and necessary changes in how teachers were prepared to teach and work with EL students. I held out hope that a Senate bill meant that there was power behind the statute.

The Council created three subcommittees to focus on different educational areas that impacted the academic needs of ELs in the state: Curriculum, Policy, and Teaching (through the TESL endorsement). Each subcommittee was charged to listen to stakeholders (parents, teachers, the school district, state institutions of higher education, and the public) and craft recommendations for change. Throughout this process, the system remained in equilibrium. Rachel experienced trepidation over what could be accomplished on the Council while Raquel was hopeful that a Senate Bill meant change could be implemented. 
Rachel

Chairing the subcommittee meant convening several meetings with the four other members selected by the Council. The subcommittee consisted of the only other Latina members, who served on the Council (two others), two White educators, a school district administrator, and a university ESL/bilingual education faculty member. All three of the Latina members, including me, had doctorates; two of us were representatives of the academy and the third represented parents on the Council.

The first few meetings I convened were to craft recommendations to modify and change the current TESL endorsement that teacher candidates and classroom teachers took to add the TESL endorsement to their credential. Subcommittee members reviewed the current requirements for the TESL endorsement, reviewed what other states with large or growing EL populations required for their endorsement, and invited the public and other stakeholders to present their thoughts, views, and concerns regarding changes to the TESL endorsement. Over the course of several lengthy meetings that included public comment, the following four recommendations were written:

1. Change the name of the old TESL endorsement to "English Language Acquisition and Development (ELAD)."

2.1. Replace the current course requirements for the TESL endorsement with new course requirements for the proposed ELAD. In addition to course name and content changes, a
Raquel

As an EL and a researcher, I knew the body of seminal and current research that told us how unprepared teachers are to teach and work with the rapidly increasing number of ELs flowing into U.S. classrooms today and how to best prepare them (Darling-Hammond \& Bransford, 2005; Gonzalez \& DarlingHammond, 2000; Lucas, Villegas, \& Freedson-Gonzalez, 2008; Walqui, 2008; Wong \& Snow, 2005). I also knew the body of work that calls for preparing all teachers and educators to better understand the complexity and diversity among ELs, their language, community, and home as pathways to instructional and academic success (Darder, 2006; Goldenberg, 2013; Moll, 2015, Scanlan \& Gundrum, 2013; Samson \& Collins, 2012; Trueba, 1999; Trueba \& Bartolomé, 2000).

All the subcommittee's members were also informed and understood the educational needs of ELs in K-12 classrooms and contributed to crafting recommendations that every teacher in the state should be prepared to work with ELs. The reality of the state, and any state for that matter, is that a teacher may not have one EL in the classroom today but could have $10 \mathrm{EL}$ students tomorrow. Why wouldn't we want to adequately prepare each and every teacher for successfully teaching each student? We believed that the recommendations we brought forward after many meetings and thoughtful deliberation were appropriate and necessary to meet the needs of the EL students within the state. Would these recommendations shake up the current system and disrupt equilibrium? Possibly. It was a matter of how much 
requirement of 25 hours of practicum in an ESL/EL classroom setting would be required.

2.2. Create an advanced endorsement named ELAD Specialist endorsement that requires the ELAD endorsement, plus two additional courses.

3.1. Recommend that all state teacher preparation programs that prepare pre-service and initial licensure students include preparation for the ELAD endorsement.

3.2. All new licensees will be required to hold the ELAD endorsement (this would impact teachers from out of state).

4. Propose that three of the six required continuing education credits needed for licensure renewal be focused on English learners or ELAD courses. the university system and the teacher licensure office wanted to meet the needs of the EL students in the state.

After many hours of meetings, debates, and discussions, the four recommendations crafted by the subcommittee were brought back to the Council for vote and approval to present to the appropriate state governing board. Of the four recommendations, Recommendation 3, including two subparts (3.1 and 3.2), was the one to require the most discussion, debate, and multiple meetings with various stakeholders. This recommendation would cause a great change to the system and would disrupt equilibrium by mandating that all current and future teachers in the state have a TESL (ELAD) endorsement. There are teachers in the state who have the TESL endorsement who choose not to teach EL students so they do not have the endorsement appear on their credential (subcommittee meeting notes, 2015). Passing this recommendation would not serve the interest of the teachers in the state, the majority of whom are White. Through her academician lens Rachel saw the recommendations as palatable to herself and possibly the governing boards who would make the final decisions. Raquel, as an EL, felt that there was much more that could be done and should be pushed forward. 


\section{Disrupting Equilibrium Begins}

Rachel

The recommendations we made seemed on par with other states that were also experiencing a large influx of EL students within their educational systems. The subcommittee felt that there were even more cutting edge requirements we could have pushed for that not only met the needs of ELs in K12 schools but would also position the state for future growth. The recommendations we finally made met the charge of the Senate Bill and would assist the educational system in meeting the needs of the EL student population. The recommendations were presented to the Council and the public since all meetings were governed by open meeting law. After minor changes all four recommendations were accepted and approved by the Council to move forward to the appropriate regulatory board.

The recommendations were presented to the appropriate regulatory boards with varying success and failure. They are discussed below in order of acceptance or denial, not numerically.

Recommendation 1 was accepted as written. The state now had a new name for the old TESL endorsement, English Language Acquisition and Development (ELAD).

Recommendation 2.1 was reworked to document the 25-hour practicum on transcripts so that the licensure office would know that the requirement was met. It was eventually accepted.

Recommendation 2.2 was passed
Raquel

Not once did the subcommittee feel we were presenting recommendations that were unattainable or "pie-in-thesky" out of reach. As each recommendation was presented to the appropriate regulatory board, I sat at a table facing the various committees and boards feeling as though I was living through the Inquisition. I often sat in disbelief as I was told why our recommendation would not work, or how much work we were creating for the licensure office, or how a credential was a teacher's property right and we could not mandate requirements to it. Or how adding an endorsement requirement would make it difficult to hire teachers, and there was a teacher shortage-- did I not know this? "What about the students you are hired to teach?" I wanted to shout back. "Don't they matter? Would any of us be here with jobs in education without them?" I was perplexed and ultimately disillusioned as I saw the simple mundane recommendations passed and the ones that would truly ignite change, the ones that would send the system into total disequilibrium, rejected. In reality, the interest of the state licensure office did not converge with the interest of the state's EL population.

Recommendation 1, or changing the name of the endorsement, was an easy change to accept. The system remained balanced and equilibrium continued.

Recommendation 2.1 caused a minor change to the system. Adding a 
since there was no official licensure process associated with the Specialist ELAD endorsement.

Recommendation 4 was initially denied. After multiple meetings with licensure personnel and Council members, this recommendation was finally accepted at hearing and moved for final acceptance.

Recommendation 3.2, that all new licensees should be required to hold the ELAD endorsement, was rejected and denied.

Recommendation 3.1 was presented to the appropriate regulatory board and after much debate was sent back to the Council for specific revision. The request was for the Council to discuss with each state institution of higher education their ability to implement the recommendation should it pass as well as to present the research that supported the need for all teachers to hold the ELAD endorsement. The Council charged the subcommittee to meet with each institution to gather information about the institution's readiness and willingness to implement the mandatory ELAD endorsement in their teacher preparation programs.

I, accompanied by a member of the state DOE, set out to visit and meet with each state institution of higher education and their ESL coordinator and interested faculty. These meetings were informative and revelatory. This recommendation will again be presented to the appropriate regulatory board. practicum that had to be recorded on a transcript makes more work for the system, but it was crafted so that the workload or change in stasis would be low and the system could make the appropriate adjustments to remain in equilibrium.

Recommendation 2.2 would provide a venue for a motivated teacher to gain more expertise in working with EL students but held no monetary incentive or licensure procedures to disrupt the system.

Recommendation 4.0 also passed because the little change that would occur to make sure upon renewal teachers took three ELAD credits was easily absorbed by the system. Teachers with a current endorsement on their credential would not have to take any of the new ELAD credits. A large cadre of senior teachers up for renewal in 10 years could retire without ever taking an ELAD course.

The biggest change to how we prepare teachers to teach and work with ELs in the classroom would have happened with recommendation 3.1 and 3.2. Recommendation 3.2 would have had every new licensee in the state required to hold the ELAD endorsement but was rejected with one of the largest school districts in the state arguing to defeat it. I was stunned. The argument was that there was a current teacher shortage in the district and adding more requirements would make it difficult to hire teachers. This recommendation would cause a complete and total disruption of the system's equilibrium, one from which they believed they could not quickly recover.

At the writing of this paper recommendation 3.1 was due for presentation later in the year, so its outcome is still uncertain. My hope is 
that teacher preparation programs realize the need for the endorsement

The machination of the system so desperate to maintain equilibrium conspired against what was best for the rapidly growing EL student population of the state. The recommendations that would not create any major change within the system passed. The recommendation that would have transformed the system completely was denied and swept off the table. I finally began to understand the underlying hegemonic practice of interest convergence; I was watching it unfold in front of me like a bad B movie with actors horribly misreading their lines.

\section{Interest-Convergence as an Interpretive Lens}

Playing out true to Interest-Convergence theory and Le Chatelier's principle of equilibrium, the recommendations that would cause minimal disruption or would benefit the system were accepted. The recommendation that could disrupt the system, requiring the ELAD endorsement for all teaching licenses, was denied. I used Le Chatelier's principle to globally describe and interpret the qualitative features of change to a system, in this case, an educational system. When an external pressure or change to the educational process is applied to the system, the system reacts to oppose or partially accommodate the pressure to maintain equilibrium. Le Chatelier's principle can provide us with a visual guide or an understanding of the back and forth nature of the system and external pressures acting upon it, but the principle only offers one glimpse to why this interplay occurs. The theory of Interest-Convergence can provide another possible explanation and interpretation of the dynamics occurring within a system trying desperately to maintain equilibrium.

The theory of Interest-Convergence, first described by Bell in 1980 (Bell, 1980; Driver, 2011), states that change will occur if it is in the best interest of or will, in some manner benefit, the interests of Whites or the dominant group. It is not the needs of the minority group that are considered primary for a change to occur; in fact, the minority group's needs will only be met if the dominant group's needs can also be accommodated in the negotiation (Bell, 1980; Driver, 2011; Milner, 2008). While Bell's theoretical foci provide a lens on how Black interests are subordinated to White interests (Bell, 1980, 2004), I use an extrapolation of the theory and apply it to mean that the interests of minority groups are subordinate to that of Whites or the dominant group. In putting forth a package of four recommendations crafted by the TESL subcommittee and approved by the Council that could, if accepted in its entirety, enact substantive change for the state's K-12 student population, the interest of the dominant population would not, in their mind, benefit. Allowing the name of the endorsement and the names and content of the required four courses to change and creating an ELAD specialist endorsement would not help the dominant group in any way, but neither would it cause any discomfort or distress to the current system in place. In fact, it would 
allow the dominant group to receive kudos for participating in what some would call progressive thinking while in actuality no substantive systemic reform had occurred.

With the passage of Recommendation 4.0 that looked at teacher license renewal, the interest of the dominant group was met. Teachers need continuing education credits to renew their license, and ELAD courses are available and offered at all state institutions of higher education and sometimes even at the district level. A teacher with seniority who needs to renew a license every 10 years can retire having taken only one or possibly two ELAD courses over a 20 -year period. This recommendation passed because the interest of the dominant group and the needs and interest of the minority group were seamlessly merged.

The biggest battle that would have been waged and caused complete disequilibrium to the system would have been Recommendation 3.1, which called for all new licensees to have the ELAD endorsement. This recommendation was most contentious, was never approved, and was systematically shot down. In essence, we were told that this recommendation would have violated the property rights of teachers in the state since, by law, a credential or license is considered a teacher's property and threatening to take a license if an endorsement is not added is a violation against the property holder.

The final segment of this saga is still in progress. Recommendation 3.2, which would mandate that all teacher preparation programs in the state include the ELAD endorsement as an integral component of teacher preparation, was denied once and will be presented for final consideration in the near future. This recommendation clearly demonstrates the interest-convergence theory. The institutions of higher education in the southern portion of the state, with the largest EL population, recognize that providing the ELAD endorsement would benefit their teachers, their institution, and the state. For these institutions, the interest of both groups merges and would benefit from the passage of the recommendation. The institutions in the north and the rural area of the state do not agree.

As Rachel, the academic, I sat on the Council and subcommittee for over two years, always listening to the whisperings of Raquel reminding me of what it was like to be an EL student in a time when they did not have a voice. I attended hours of meetings, flew across the state to participate in meetings and interview administrators, and felt that little substantive progress was made. As an untenured faculty member, I challenged tenured faculty and administrators at my institution. I was informed by one tenured faculty member in a meeting that I was engaging in what he called "academic suicide." I do not yet know how this story will end for me, or the EL K-12 population, but I do know that I will continue to seek other methods of serving the EL student population in this state. Padilla (1994) calls the dichotomous tension between the desire to serve his/her cultural and/or linguistic community in a specified capacity and the involuntary placement of service and possibly not being rewarded for this service "cultural taxation" (p. 26). Many faculty of color in the academy find themselves under "cultural taxation" (Turner, 2003). Yet Ladson-Billings (1997) encourages us to not despair but to work toward changing the academy so we can be true to ourselves as faculty and researchers of color. 


\section{Conclusion}

I used autoethnography as a method to tell my academic story as Rachel and provide autobiographical counterstories (Yosso, 2006) as an analysis of the experience of Raquel. I positioned my work using Chang's (2008) triadic balance, situating autoethnography as "ethnographic in methodological orientation, cultural in its interpretive orientation, and autobiographical in its content orientation" (p. 48). The data I used to create my story consisted of many forms of documentation. The data included my notes during Council, TESL subcommittee and special meetings with stakeholders, as well as comments and reactions I scribbled to myself in the margins of the notes. I used the official minutes from all Council, TESL Subcommittee, COPS, SBE meetings and notes from the individual meeting with each institution of higher education in the state. I also relied on my memories of schooling experiences as well as kindergarten school documents such as report cards. I created counterstories and narratives, in the voice of Raquel, as a form of analysis to respond to and expand upon Rachel's academic story (Elenes, 2000; Solórzano \& Yosso, 2002). My counterstories sought to document my perspective of the insidiousness of interest convergence at work within a state's educational system fighting against change and to maintain the status quo. Finally, the interpretive nature of interest-convergence (Bell 2004; Driver, 2011; Milner, 2008) and Le Chatelier's principle of equilibrium provided clarity and an unapologetic presentation of the data. The data support the theory of interest-convergence and Le Chatelier's principle of equilibrium. The recommendations that were passed were ones that would not cause major disruption to the educational systems' (districts, higher education) function nor would they interfere with the interest of the White majority. The one recommendation that was denied would have benefited the EL student population but not the White majority of educators.

As Raquel, it is difficult not to feel a sense of failure and disappointment that the subcommittee I led (as Rachel) could not successfully counter embedded hegemonic practices and lead the charge for actual transformative change for the EL students enrolled in the state's K-12 school system. Trueba (1999) calls upon us to denounce "hegemonic classroom control" (p. 612) and to promote authentic pedagogies. I call upon EL educators to join forces with EL students and their families and demand the equal education that they deserve and that is mandated by law. Educational systems (school districts, higher education, etc.) at all levels should be compelled to acknowledge whether they are indeed enacting their mission statement or merely providing lip service. I will continue to look for avenues to enact change within the system so the "Raquels" throughout the state can keep their name, their language, and proudly teach others how to pronounce it correctly in English and in their home language. I have reclaimed Raquel but only invite a select few to call me by name. 


\section{References}

Bell, D. (2004). Silent covenants: Brown v. Board of Education and the unfulfilled hopes of racial reform. New York, NY: Oxford University Press.

Bell, D. (1980). Brown vs. Board of Education and the interest-convergence dilemma. Harvard Law Review, 93, 518-533.

Bulale, N. (2016). Why it's important to honor home languages in schools. The Seattle Globalist. Retrieved from http://www.seattleglobalist.com/ 2016/02/16/homelanguage-learning-ell-seattle-highline-schools/47462/

Darling-Hammond, L., \& Bransford, J. (2005). Preparing teachers for a changing world: What teachers should learn and be able to do. San Francisco, CA: Jossey-Bass.

Delgado Bernal, B. (2002). Critical race theory, Latino critical theory, and critical racedgendered epistemologies: Recognizing students of color as holders and creators of knowledge. Qualitative Inquiry, 8(1), 105-126.

Boylorn, R. M., \& Orbe, M. P. (Eds). (2014). Autoethnography intersecting cultural identities in everyday life. Walnut Creek, CA: Left Coast Press.

Chang, H. (2008). Autoethnograpy as method. Walnut Creek, CA: Left Coast Press.

Darder, A. (2006). Latino youth: Pedagogy, praxis and policy. Latino Studies, 4(3), 302304.

Driver, J. (2011). Rethinking the interest-convergence thesis. Northwestern University Law Review, 105(1),149-198.

Garza, E. (2008). Autoethnography of a first time superintendent: Challenges to leadership for social justice. Journal of Latinos and Education, 7(2), 163-176.

Goldenberg, C. (2013). Unlocking the research on English learners: What we know and don't know yet about effective instruction. American Educator, 37(2), 4-11.

Gonzalez, J. E., \& Darling-Hammond, L. (2000). Programs that prepare teachers to work effectively with students learning English. ERIC Digest. Washington, D.C.: ERIC Clearinghouse on Languages and Linguistics.ED447724.

Last, A. M., \& Slade, P. W. (2007). A colorful demonstration of Le Chatelier's Principle. Journal of College Science Teaching, 27(2), 143-145.

Ladson-Billings, G. (1997). For colored girls who have considered suicide when the academy's not enough: Reflections of an African American woman scholar. In A. Neumann \& P. Peterson (Eds.), Learning from our lives: Women, research, and autobiography in education (pp. 52-70). New York, NY:Teachers College.

Lopez, F., Scanlan, M., \& Gundrum, B. (2013). Preparing teachers of English language learners: Empirical evidence and policy implications. Education Analysis Archives 21(20), 1-32. Retrieved from http://epaa.asu.edu/ ojs/article/view/1132 
Lucas, T., Villegas, A. M., \& Freedson-Gonzalez, M. (2008). Linguistically responsive teacher education preparing classroom teachers to teach English language learners. Journal of Teacher Education, 59(4), 361-373.

Madison, D. S. (2012). Critical ethnography: Methods, ethics, and performance $\left(2^{\text {nd }}\right.$ ed.). Thousand Oaks, CA: Sage.

Ruiz Soto, A. G., Hooker, S., \& Batalova, J. (2015). States and districts with the highest number and share of English language learners. Migration Policy Institute Fact Sheet. Retrieved from http://www.migrationpolicy.org/ research/states-anddistricts-highest-number-and-share-english-language-learners/

Milner, R. H. (2008). Critical race theory and interest convergence as analytic tools in teacher education policies and practice. Journal of Teacher Education, 59(4), 332-346.

Moll, L. C. (2015). Tapping into the "hidden" home and community resources of students. Kappa Delta Pi Record, 51(3), 114-117.

National Assessment of Educational Progress. (2015). The nation's report card: 2015 mathematics and reading assessments. Washington, DC: NCES. Retrieved from http://www.nationsreportcard.gov/reading_math_2015/ \#?grade=4

Padilla, A. M. (1994). Ethnic minority scholars, research and mentoring: Current and future issues. Educational Researcher, 23(4), 24-27.

Pew Research Center. (2013). Demographic Profile of Hispanics in Nevada, 2011. Retrieved from http://www. pewhispanic.org/states/state/nv/

Samson, J. F., \& Collins, B. A. (2012). Preparing all teachers to meet the needs of English language learners: Applying research to policy and practice for teacher effectiveness. Washington, DC: Center for American Progress.

Solórzano, D. G., \& Bernal, D. D. (2001). Examining transformational resistance through a critical race and LatCrit theory framework Chicano and Chicana students in an urban context. Urban Education, 36(3), 308-342.

Solórzano, D. G., \& Yosso, T. J. (2002). Critical race methodology: Counter-storytelling as an analytical framework for educational research. Qualitative Inquiry, 8(1), 2344.

Sumaryono, K., \& Ortiz, F. W. (2004). Preserving the cultural identity of the English language learner. Voices in the Middle, 11(4), 16-19.

Trueba, H. T. (1999). Critical ethnography and Vygotskian pedagogy of hope: The empowerment of Mexican immigrant children. Qualitative Studies, 12(6), 591614.

Trueba, H. T., \& Bartolomé, L. I. (2000). Immigrant voices: In search of education equity. Lanham, MD: Rowman \& Littlefield Publishers.

Turner, C. (2003). Incorporation and marginalization in the academy from border to center for faculty of color? Journal of Black Studies, 34(1), 112-125. 
Yosso, T. (2006). Critical race counter stories along the Chicana/Chicano education pipeline. New York, NY: Routledge.

Walqui, A. (2008). The development of teacher expertise to work with adolescent English learners: A model and a few priorities. In L. S. Verplaetse \& N. Migliacci (Eds.), Inclusive pedagogy for English language learners: A handbook of research-informed practices (pp. 103-125). New York, NY: Lawrence Erlbaum.

Wong, F. L., \& Snow, C. E. (2000). What teachers need to know about language. Washington, DC: Department of Education's Office of Educational Research and Improvement, Center for Applied Linguistics no. ED-99-CO-0008).

\section{Author Contact}

Rachel G. Salas: rgsalas@unr.edu

College of Education, University of Nevada-Reno, 1664 N. Virginia Street, Reno, NV 89557, USA 